\title{
Changes to the tropical circulation in the mid-Pliocene and their implications for future climate
}

\author{
Shawn Corvec $^{1}$ and Christopher G. Fletcher ${ }^{2}$ \\ ${ }^{1}$ Department of Applied Mathematics, University of Waterloo, 200 University Ave W, Waterloo, Ontario, N2L 3G1, Canada \\ ${ }^{2}$ Department of Geography and Environmental Management, University of Waterloo, 200 University Ave W, Waterloo, \\ Ontario, N2L 3G1, Canada \\ Correspondence to: Shawn Corvec (scorvec@uwaterloo.ca)
}

Received: 2 August 2016 - Discussion started: 18 August 2016

Revised: 17 January 2017 - Accepted: 29 January 2017 - Published: 16 February 2017

\begin{abstract}
The two components of the tropical overturning circulation, the meridional Hadley circulation (HC) and the zonal Walker circulation (WC), are key to the re-distribution of moisture, heat and mass in the atmosphere. The midPliocene Warm Period (mPWP; 3.3-3 Ma) is considered a very rough analogue of near-term future climate change, yet changes to the tropical overturning circulations in the MPWP are poorly understood. Here, climate model simulations from the Pliocene Model Intercomparison Project (PlioMIP) are analyzed to show that the tropical overturning circulations in the mPWP were weaker than preindustrial circulations, just as they are projected to be in future climate change. The weakening $\mathrm{HC}$ response is consistent with future projections, and its strength is strongly related to the meridional gradient of sea surface warming between the tropical and subtropical oceans. The weakening of the WC is less robust in PlioMIP than in future projections, largely due to inter-model variations in simulated warming of the tropical Indian Ocean (TIO). When the TIO warms faster (slower) than the tropical mean, local upper tropospheric divergence increases (decreases) and the WC weakens less (more). These results provide strong evidence that changes to the tropical overturning circulation in the $\mathrm{mPWP}$ and future climate are primarily controlled by zonal (WC) and meridional (HC) gradients in tropical-subtropical sea surface temperatures.
\end{abstract}

\section{Introduction}

The tropical overturning circulation driven by tropical convection is an important driver of the hydrological cycle of the tropics and subtropics. Additionally, variability in tropical convection can cause changes to midlatitude weather patterns on a wide range of timescales (e.g., Weickmann et al., 1985; Roundy et al., 2010; Lau and Phillips, 1986; Trenberth et al., 1998). The tropical overturning circulation can be broken down into zonal (Walker circulation; henceforth WC) and meridional (Hadley circulation; henceforth HC) components. Both the WC and HC are susceptible to external forcing, and numerous studies have shown - both theoretically and through modeling - that the WC and HC (at least in the Northern Hemisphere) will weaken in response to climate change (e.g., Vallis et al., 2015; Bony et al., 2013; He and Soden, 2015; Vecchi and Soden, 2007; Gastineau et al., 2009). This is associated with an overall weakening of the global hydrological cycle and weaker convective updrafts over the tropical oceans (e.g., Vecchi and Soden, 2007; Held and Soden, 2006).

Observation-based analysis for the historical period, and modeling studies for historical and future periods, however, are inconclusive about important aspects of the tropical circulation response to climate change. An alternative line of investigation is to use a paleoclimate interval, such as the mid-Pliocene warm period (henceforth mPWP; ca. 3.3$3 \mathrm{Ma}$ ), as an imperfect analogue of present and near-future climate (e.g., Robinson et al., 2008). The mPWP was the most recent period where $\mathrm{CO}_{2}$ concentrations were similar to those levels that are projected to be reached this century 
(Raymo et al., 1996) and the continental configuration was highly similar (relative to other paleoclimate intervals further in the past) to present (Dowsett, 2007a). Since a wealth of paleoclimate data is available for the MPWP, and its climate conditions are expected to be similar to the climate of the near future (Dowsett, 2007a), this interval is considered useful for validation of future climate simulations. Previous modeling studies examining changes to the tropical circulation in the mPWP found a weakening of the $\mathrm{WC}$ and $\mathrm{HC}$ similar to studies examining future climate (Kamae et al., 2011; Sun et al., 2013), but these are single-model studies only, where the results could be skewed by individual model biases.

One of the key features of the mPWP derived from paleoclimate records was significantly warmer high-latitude regions compared to present, with relatively similar tropical sea surface temperatures (SSTs) to modern (Dowsett et al., 1992, 1994, 1996; Raymo et al., 1996). There are also strong indications that the upwelling regions off the coast of western South America were much warmer than present, causing a weakening of the west-east SST gradient in the tropical Pacific and indicating a flattening of the thermocline (Dekens et al., 2007; Dowsett and Robinson, 2009). These changes in zonal and meridional SST gradients could have had important effects on the tropical overturning circulation of the mPWP, and studying these effects could provide insight into the usefulness of the mPWP as an analogue for future climate change since they differ significantly from present day.

Multiple effects due to increased greenhouse gases (GHGs) can slow down the tropical overturning circulation (Vallis et al., 2015). Initially, GHG forcing alone warms the free troposphere, which tends to increase atmospheric static stability over the tropical oceans and reduce convective precipitation. This effect, sometimes referred to as the "direct" GHG forcing, occurs almost immediately after GHG is increased, as the mid-upper troposphere warms in response to decreased radiative cooling to space (Bony et al., 2013). An indirect effect of GHG forcing is warming of the surface, with the land warming almost instantaneously, and ocean warming lagging by several decades, causing increased landsea temperature contrasts (Bayr and Dommenget, 2012). This tends to lower surface pressures over land, relative to the oceans, which leads to an increased land-sea pressure gradient, moisture convergence and precipitation over land, and a strengthening of the monsoonal circulations (e.g., $\mathrm{Hu}$ et al., 2000). The delay in surface warming over the oceans increases static stability there as the free troposphere warms, while stability is either unchanged or decreases over land where surface temperatures can warm at a similar rate to the free troposphere (Bayr and Dommenget, 2012).

Eventually the SSTs also warm, increasing boundary layer specific humidity, which - assuming fairly constant relative humidity under climate change (Vecchi and Soden, 2007) - increases nonlinearly with increasing temperature by the Clausius-Clapeyron relation. In order for precipitation to balance evaporation on a global scale, and since most precipitation occurs through convection in the tropics, the tropical convective mass flux must decrease (Held and Soden, 2006). In other words, tropical convective updrafts do not have to be as strong as before to maintain the balance between evaporation and precipitation due to the increased water vapor content due to climate change.

A factor that can alter local (although not global mean) tropical convection from increasing GHGs is the spatial pattern of the SST warming. Regions where SSTs warm faster (slower) than the tropical mean are likely to experience smaller (larger) increases in static stability than the tropical mean. This is because the warming of the tropical troposphere is fairly uniform since temperature gradients are difficult to maintain there (Ma and Xie, 2012). This change to the regional pattern of tropical convection, caused by the pattern of SST warming and increased land-sea contrast, could lead to a redistribution of tropical and subtropical precipitation (e.g., Bayr and Dommenget, 2012; Chadwick et al., 2012).

The weakening of the tropical zonal overturning circulation (WC) is among the most robust responses of the tropical circulation to future climate change (He and Soden, 2015; Vecchi and Soden, 2007). The primary driver of the projected slowdown of the WC is thought to be from warming SSTs and associated reduction in convective mass flux (Held and Soden, 2006; He and Soden, 2015; Ma et al., 2011; Lu et al., 2007; Vecchi and Soden, 2007). Additionally, it is well known that the WC strength can be modulated by the zonal gradient in tropical SST (Bjerknes, 1966); for example, on interannual timescales the warm phase of ENSO (El Niño-Southern Oscillation) reduces the zonal SST gradient and weakens the WC. Thus, any change to zonal SST gradients resulting from increased GHGs is likely to be important for modulating the WC response to climate change. During the mPWP, the zonal SST gradient in the tropical Pacific is thought to have been much weaker than present - primarily due to warmer SSTs in the upwelling regions off the west coast of South America - causing the WC to be weaker than present (Kamae et al., 2011). Observations and reanalysis data show contradictory trends in recent WC strength over the satellite era, with some indicating weakening (e.g., Vecchi et al., 2006; Power and Kociuba, 2010) and others indicating strengthening (e.g., L'Heureux et al., 2013; McGregor et al., 2014). Nonetheless, future projections from the Coupled Model Intercomparison Project Phase 5 (CMIP5) (Taylor et al., 2011) indicate a robust weakening of the WC and overall tropical overturning circulation over the 21 st Century, which is associated with reductions in the zonal gradient of tropical SSTs (Shin and Sardeshmukh, 2010; Ma and Xie, 2012; He and Soden, 2015).

The weakening of the meridional overturning circulation (HC) in response to climate change is less robust than the weakening of the WC. A poleward expansion of the descending branch of the $\mathrm{HC}$ in the wintertime Northern Hemisphere is considered the most robust projection for the future re- 
sponse (Lu et al., 2007; Kang and Lu, 2012). Additionally, as the troposphere warms, the $\mathrm{HC}$ is expected to expand vertically as the tropopause height increases in the tropics, an effect which may already be apparent in observations (Santer et al., 2003). The CMIP5 models show fairly good agreement for a weakening of the northern hemispheric $\mathrm{HC}$, with substantial disagreement over the response of the southern hemispheric cell (He and Soden, 2015; Ma and Xie, 2012; Vecchi and Soden, 2007). However, satellite observations and reanalysis data suggest that the $\mathrm{HC}$ has, in fact, strengthened rather than weakened since 1979 (Mitas and Clement, 2005; Liu et al., 2012). This apparent contradiction may be the result of poor model parameterization of clouds or convection (e.g., Mitas and Clement, 2006; Sohn et al., 2016) or due to natural variability. For example, internal fluctuations in the tropical and extratropical oceans have effects on the tropical circulation in the short term that could be masking a longerterm trend (Kosaka and Xie, 2013).

Part of the variability in HC strength could be explained by changes in meridional SST gradients, which have been shown to weaken (strengthen) the $\mathrm{HC}$ if these gradients weaken (strengthen) (e.g., Seo et al., 2014; Levine and Schneider, 2010; Williamson et al., 2013; Gastineau et al., 2009; Kamae et al., 2011). The meridional SST gradient from the tropics to the poles is greatly reduced in the MPWP (e.g., Haywood et al., 2013; Dowsett et al., 1996; Dowsett and Robinson, 2009), which to leading order weakens the $\mathrm{HC}$ as shown in Kamae et al. (2011). This reduced-meridional-SSTgradient world can provide a test bed for the climate models to better gauge the sensitivity of the $\mathrm{HC}$ to these boundary conditions.

Our study aims to examine the tropical circulation of the mPWP using multiple general circulation models (GCMs). Our paper attempts to show the similarities and differences of the tropical circulation of the mid-Pliocene to the tropical circulation under anthropogenic climate change. As such, the mPWP provides a unique opportunity to gain a better understanding of large-scale climate dynamics in a warmer world. The structure of this article will be as follows: Sect. 2 will explain the model dataset and diagnostics that will be used for our analysis in the data and methods section. Then Sect. 3 will examine the modeled tropical circulation of the mPWP with comparisons to CMIP5, broken down into one section for the WC and one for the HC. Section 4 will present further discussion and our primary conclusions.

\section{Data and methods}

\subsection{Climate model simulations}

To examine the tropical circulation of the mPWP, we used the Pliocene Model Intercomparison Project (PlioMIP), which aims to simulate the climate of the mPWP (Haywood et al., 2010, 2011). Two different groups of models were run; atmosphere-only general circulation models (AGCMs)
Table 1. The list of models available from PlioMIP for the prescribed SST (PRES) and coupled ocean-atmosphere (CPLD) experiments. The " $X$ " (dash) indicates that the model data are available (unavailable). Two models in CPLD (GISS and NCAR CCSM4) do not have equivalents in PRES (we elected not to use data from NCAR CAM3.1 because it was not available for pressure levels). In the left column, the letter in parentheses after the model name shows its index in Fig. 6. The right column shows the tropical $\left(30^{\circ} \mathrm{S}-\right.$ $\left.30^{\circ} \mathrm{N}\right)$ mean near-surface air temperature response $(\Delta \mathrm{Ts}$, units $\mathrm{K})$ for each model in CPLD.

\begin{tabular}{lrrr}
\hline \multicolumn{4}{c}{ PlioMIP model list } \\
\hline Model (letter) & PRES & CPLD & $\begin{array}{r}\text { CPLD } \Delta \text { Ts } \\
(\mathrm{K})\end{array}$ \\
\hline GISS (A) & & & 1.36 \\
HadCM3 (B) & $\mathrm{X}$ & $\mathrm{X}$ & 2.56 \\
MIROC4m (C) & $\mathrm{X}$ & $\mathrm{X}$ & 2.58 \\
MRI-CGCM2.3 (D) & $\mathrm{X}$ & $\mathrm{X}$ & 1.48 \\
NCAR CCSM4 (E) & - & $\mathrm{X}$ & 1.24 \\
NorESM-L (F) & $\mathrm{X}$ & $\mathrm{X}$ & 1.89 \\
\hline
\end{tabular}

and coupled ocean-atmosphere general circulation models (AOGCMs). The AGCM models use a prescribed monthly SST climatology that does not change through the integration, while the AOGCM SSTs are allowed to evolve freely. Hereafter, we refer to the AGCM model group as PRES (for prescribed SSTs) and the AOGCM group as CPLD (for coupled ocean-atmosphere models). The mid-Pliocene boundary conditions are based on the Pliocene Research, Interpretation and Synoptic Mapping Phase 3 (PRISM3) paleoclimate reconstructions (Dowsett et al., 2010). A list of the PlioMIP models examined in this study is included in Table 1 , and further details on the experiments and model configuration can be found in Haywood et al. (2013).

The experimental setup for each group of models is as follows. Atmospheric $\mathrm{CO}_{2}$ levels are set at $405 \mathrm{ppm}$ for both groups of models, while all other GHGs are kept the same as the preindustrial (PI) control runs. Additionally, the solar constant, orbital parameters and aerosol concentrations are kept the same as PI as well. Sea surface temperature, coastlines, vegetation type and ice sheet boundary conditions are specified from PRISM3 (Dowsett et al., 2010). The models in PRES are run with an integration length of 50 years, with 20 years for spin-up, giving 30 years of mid-Pliocene climatology. The models in CPLD are run with an integration length of 500 years or longer to allow the ocean to fully equilibrate to the increase in GHGs. Note that the PRISM3 boundary conditions employ a technique described as "warm peak averaging" by Dowsett and Poore (1991) to represent the average conditions of the warm periods over the approximately $300 \mathrm{ky}$ duration of the mPWP. It has been suggested that using paleoclimate reconstructions over such a long period may not be appropriate because shorter-term fluctuations in climate forced by changes in orbital parameters mean 
that proxy data may not be representative of conditions from the time period consistent with the boundary conditions (e.g., Salzmann et al., 2013). Indeed, over the $\sim 300 \mathrm{ky} \mathrm{mPWP,}$ it has been shown that solar insolation exhibited very large fluctuations (Laskar et al., 2004). The next phase of the PlioMIP project, PlioMIP2, will mitigate this issue by focusing on a narrower time period at $3.2 \mathrm{Ma}$, with consistent orbital and SST forcing.

\subsection{Climate diagnostics}

To compute diagnostics to measure tropical circulation change, some post-processing was necessary on the data from PlioMIP. The data were interpolated to a $2.5 \times 2.5^{\circ}$ grid for all models to create a common resolution for computing multi-model mean statistics. We define the response as the difference, for any given quantity, between the mPWP simulation and the PI control simulation for each model. The response is evaluated using monthly mean climatologies computed over all available years of simulation (typically 150 years in most models). Meridional wind data were available on 10 common vertical levels between 1000 and $100 \mathrm{hPa}$ for all models listed in Table 1. Lastly, if a model did not contribute output to the CPLD experiment, it was not included in our analysis.

We compute multi-model means for PRES and CPLD using the models listed in Table 1. Each model's response is first scaled by its tropical mean $\left(30^{\circ} \mathrm{S}-30^{\circ} \mathrm{N}\right)$ surface temperature response in CPLD (Table 1), consistent with the procedure followed for future climate simulations by $\mathrm{He}$ and Soden (2015). In figures showing multi-model means, stippling indicates regions of agreement across the model ensemble and is added where all but one member in the model group agree on the sign of the response. The small number of models in each PRES and CPLD prevents a more robust statistical analysis of the model agreement. JJA refers to a 3-month June-July-August mean, while DJF refers to a 3month December-January-February mean.

To diagnose changes to the $\mathrm{HC}$, zonally averaged meridional mass stream function $(\Psi)$ was calculated (Oort and Yienger, 1996), then latitude-height cross sections of this quantity were created. This field highlights the vertical and meridional circulation associated with the $\mathrm{HC}$, with positive (negative) values indicating clockwise (counterclockwise) overturning. To diagnose changes to the $\mathrm{WC}$, we use upper-tropospheric $(200 \mathrm{hPa})$ velocity potential $(\chi)$, which is anticorrelated with regions of divergence (convergence) that are strong indicators of upwelling (downwelling) associated with the WC. We also use sea level pressure (SLP) to diagnose changes to the WC and overall tropical overturning circulation (SLP data were not available from the MIROC4m model).

\section{Simulated changes to the tropical circulation during the mid-Pliocene}

\subsection{Response of the tropical climate}

We begin with a brief overview of the simulated changes to the multi-model mean, annual mean tropical climate in the mPWP, relative to the PI. In CPLD the tropical oceans warm by $\sim 0.5-1.5 \mathrm{~K}$ (Fig. 1a), and tropical land regions generally warm even more than the oceans (upwards of $5 \mathrm{~K}$ in some arid regions). The $850 \mathrm{hPa}$ wind response indicates a strengthening of the easterly trade winds across much of the tropics and subtropics, with indications of strengthened southwesterly monsoonal flow over the northwestern Indian Ocean.

Over a large region of the tropical ocean, the imposed SST perturbation in PRES (Fig. 1b) shows weak warming compared to PI. The only region that sees significant warming in the tropics in PRES is the eastern Pacific, especially near the coast of South America, with some regions warmer by up to $5 \mathrm{~K}$, which drastically weakens the west-east SST gradient in the tropical Pacific. The PRES simulations do warm in the subtropics, and they show even greater warming (by a factor of 1.2 in the Northern Hemisphere (NH) and 1.1 in the Southern Hemisphere (SH)) than CPLD in the extratropics, especially at high latitudes (not shown). Additionally, the tropics $\left(30^{\circ} \mathrm{S}-30^{\circ} \mathrm{N}\right)$ warm more in CPLD $(1.75 \mathrm{~K})$ than in PRES (0.95). This acts to reduce the meridional equator-pole surface temperature gradient more in PRES than in CPLD.

Tropical precipitation generally increases in CPLD, particularly over the oceans at the outer edges of the climatologically "wet" zones (Fig. 2a). This pattern indicates an expansion of the wet regions on both sides of the equator, but with a significantly stronger response in the NH. Land precipitation increases substantially in a band covering the Sahel, the Middle East and southern Asia. By contrast, precipitation decreases over the South Atlantic, the eastern South Pacific Convergence Zone (SPCZ) and over continental southern Africa and Amazonia.

The precipitation response in PRES (Fig. 2b) is rather different to that in CPLD, with moderate decreases over the climatological wet regions and increases over much of the southern tropical ocean including over the eastern SPCZ. While precipitation increases poleward of the northern Intertropical Convergence Zone (ITCZ) in CPLD and PRES, in PRES it decreases on the southern flank along the equator. Land precipitation shows similar or even stronger increases than CPLD in the band between northern Africa and southern Asia, and over Australia, regions where the simulated response agrees closely with available paleoclimate records (Salzmann et al., 2013; Kamae et al., 2011). The enhanced rainfall over relatively arid land regions is consistent with enhanced monsoonal activity (Bayr and Dommenget, 2012). We note that the largest differences in precipitation response 

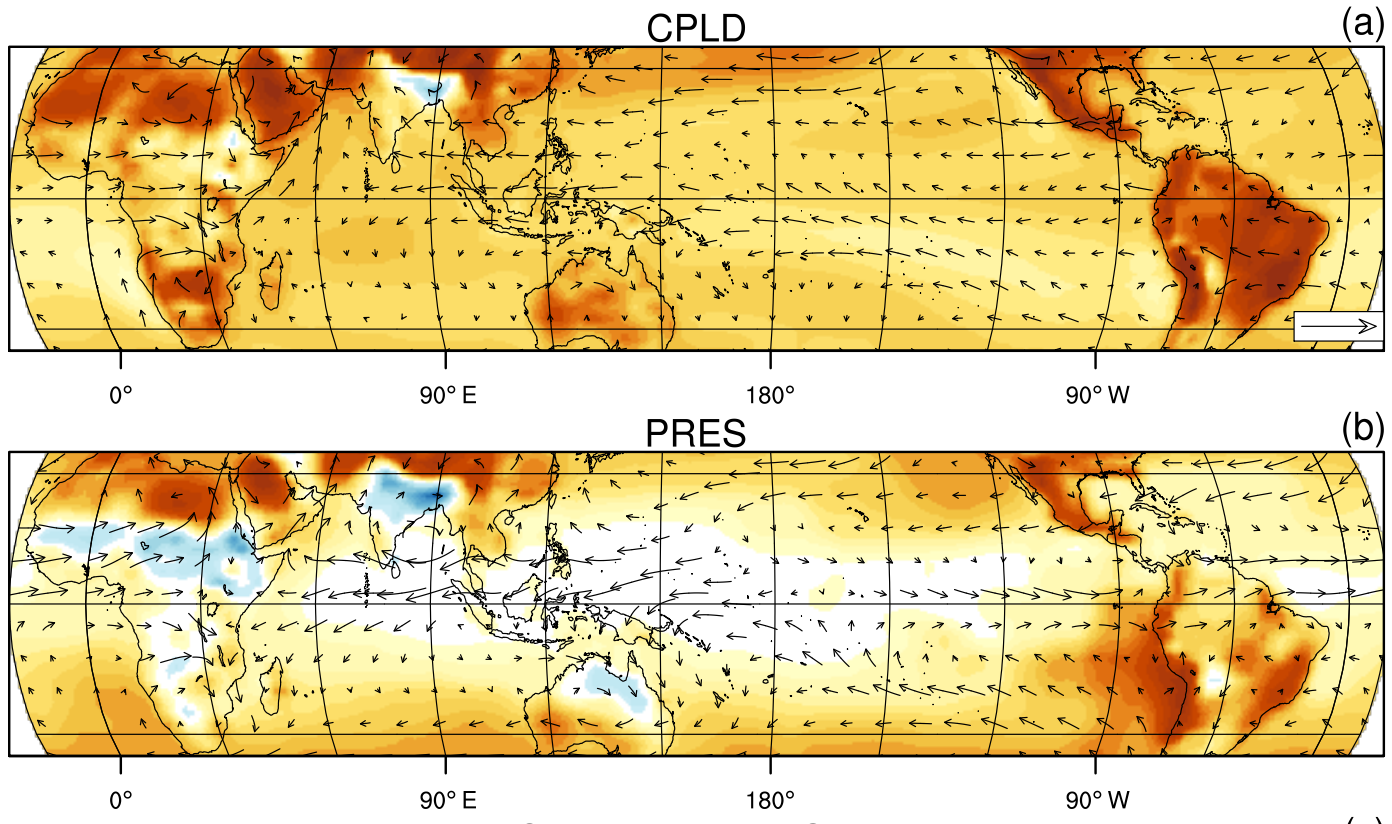

CPLD minus PRISM3

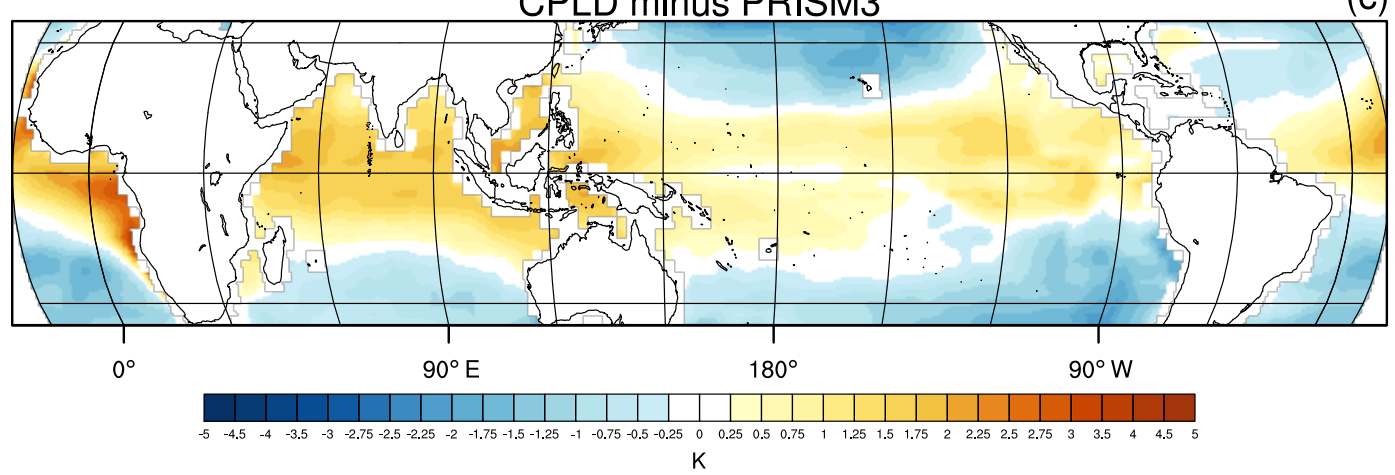

Figure 1. CPLD (a) and PRES (b) multi-model mean, annual mean surface temperature response (shading, units $\mathrm{K}$ ) and $850 \mathrm{hPa}$ wind response (reference vector denotes $3 \mathrm{~m} \mathrm{~s}^{-1} \mathrm{~K}^{-1}$ ). Prior to computing the multi-model mean, the response in each model is scaled by its tropical mean surface temperature response in CPLD (see Sect. 2.2 and Table 1). (c) CPLD multi-model annual mean sea surface temperature (SST) minus PRISM3 reconstructed SST.

between CPLD and PRES (Fig. 2) occur where there are the largest differences in SST warming (Fig. 1).

\subsection{Response of the Walker circulation}

The ascending branch of the annual mean WC is located over the Maritime Continent, where the region of strongest climatological upper-tropospheric divergence (negative $200 \mathrm{hPa} \chi)$ indicates large-scale ascent and convective outflow (Fig. 3a). The compensating descending branch of the climatological WC is located over the eastern Pacific in a region of strong convergence. The response of the WC to mPWP climate change in CPLD indicates a slight $(\sim 3-4 \%)$ weakening of the $\chi$ field over the Maritime Continent (based on the multi-model mean of the percentage change of the absolute value of the minima in the $200 \mathrm{hPa} \chi$ field for each model in that region), a strengthening over the eastern $\mathrm{Pa}$ - cific and a westward shift of the ascending branch over the western Indian Ocean (Fig. 3a). However, the weakening of the ascending branch is not robust, as indicated by a lack of model consensus on the sign of the response, with two models (NCAR CCSM4 and NorESM-L) showing a slight strengthening.

The WC response in PRES shows an unambiguous weakening, with decreased divergence over the western Pacific and Indian oceans, and increased divergence over Africa (Fig. 3b). The pattern of $\chi$ response projects negatively onto the background climatological $\chi$ : weakening of the divergence is focused in the regions of strongest climatological ascent, extending from the Indian Ocean into the western and central Pacific, and increased divergence is found over the eastern Pacific near the climatologically descending limb of the WC. The overall weakening response of the WC in PRES is highly robust among the different models - more so than 

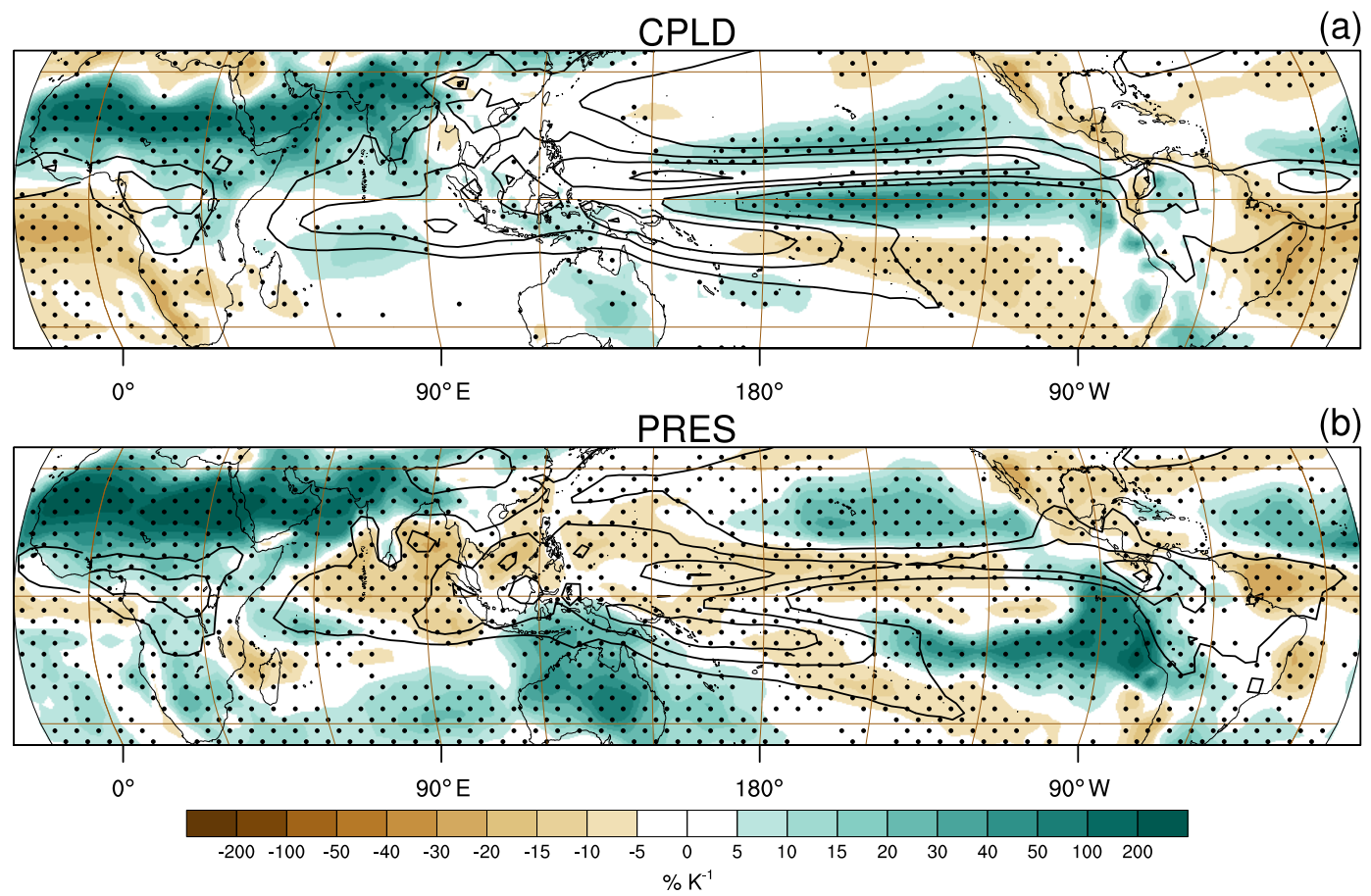

Figure 2. As Fig. 1, except showing the precipitation response as a percentage of the preindustrial control climatology (shading). The precipitation rate from the preindustrial control climatology is shown by thick black contours, interval $2 \mathrm{~mm} \mathrm{~d}^{-1}$ and starting at $4 \mathrm{~mm} \mathrm{~d}^{-1}$. Stippling indicates regions where at least all but one of the models in the model group agree on the sign of the response.

for CPLD - with unanimous agreement on the sign, which suggests a role for tropical SST changes. However, there is a large spread among the four models in PRES for the WC weakening of $\sim 1-29 \%$ using the same WC strength-change metric used for CPLD.

Another way to examine the WC response is through the surface response, by using SLP to measure changes in the mass distribution of the atmosphere. In Fig. 4a, b we show, for both groups of models, that the SLP response displays a similar pattern of WC response to that obtained using $\chi$. In CPLD, the tropics show relatively minor changes in SLP, with an increase over the Maritime Continent and western Pacific and a decrease over the Indian Ocean associated with increased ascent and upper-level divergence there (see Figs. 4a, 3a). This pattern represents a minor weakening of the climatological zonal gradient in tropical SLP (not shown), consistent with weakening of the WC in CPLD. By contrast, the PRES experiment shows an increase in SLP across the Maritime Continent and into the western-central tropical Pacific, with a smaller increase in the eastern Pacific. This pattern represents a more pronounced weakening of the zonal gradient in tropical SLP, consistent with a more substantial weakening of the WC in PRES than in CPLD.

The patterns of $\chi$ and SLP response in the tropics are driven, to leading order, by changes to tropical convection, which drives the mass circulation and hence the WC (e.g., Gill, 1980; Sasamori, 1982). Since the tropical tropo- sphere warms uniformly in response to climate change, local changes in static stability must be controlled by changes in local surface temperature (Ma and Xie, 2012; Xie et al., 2010). To investigate the role of local surface warming we define the quantity $\mathrm{dSST}^{*}$ as the difference between the local SST response and the tropical $\left(20^{\circ} \mathrm{S}-20^{\circ} \mathrm{N}\right)$ mean SST response in each model for both PRES and CPLD (Fig. 4a, b, shading). There is a very strong association between the spatial pattern of dSST* and that of the SLP response (anomaly correlation of -0.65 for the multi-model mean and a range of -0.56 to -0.66 for the 10th-90th percentile of CPLD models), and also with $200 \mathrm{hPa} \chi$ (anomaly correlation of -0.57 for the multi-model mean, with a range of -0.43 to -0.6 for the 10th-90th percentile of CPLD models). The SLP $(\chi)$ response tends to show high pressure (upper-tropospheric convergence) over regions where dSST* is negative; that is, there is large-scale descent where the local warming is less than the tropical mean warming. This may explain why the WC weakens less in CPLD than in PRES because the pattern of surface warming in CPLD produces a maximum located in regions of climatological divergence and ascent, particularly in the eastern Indian Ocean and around the Maritime Continent.

To further investigate the relation between the pattern of SST warming in CPLD and the WC, a correlation between dSST $*$ averaged over $90-150^{\circ} \mathrm{E}, 20^{\circ} \mathrm{S}-20^{\circ} \mathrm{N}$ and WC strength change (using the method defined earlier in this 

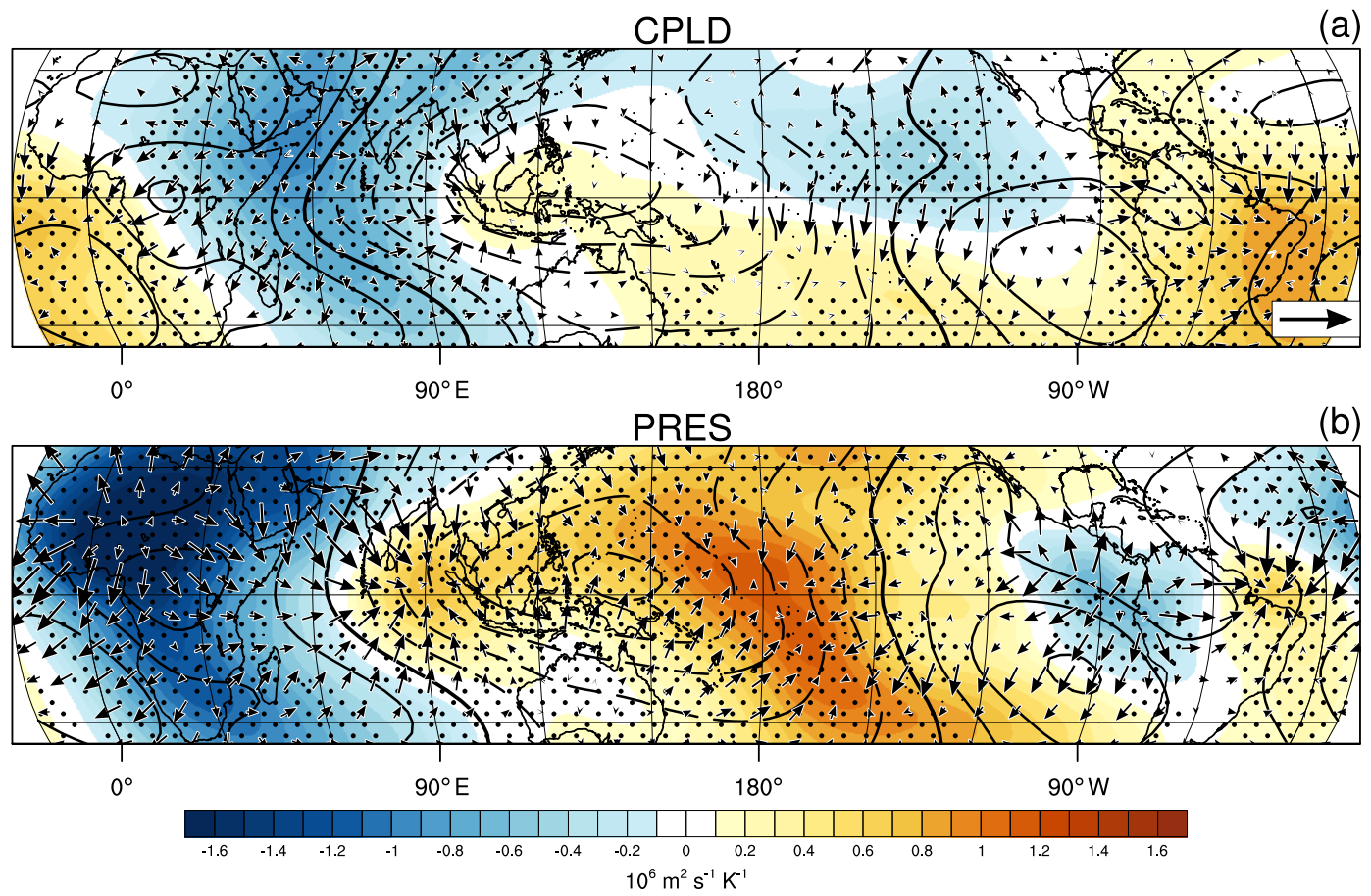

Figure 3. As Fig. 1, except showing the $200 \mathrm{hPa}$ annual mean velocity potential $(\chi)$ response (shading) and $200 \mathrm{hPa}$ divergent wind annual mean response vectors (reference vector denotes $1 \mathrm{~m} \mathrm{~s}^{-1} \mathrm{~K}^{-1}$ ). Contours show $200 \mathrm{hPa} \chi$ from the preindustrial control climatology, interval $2 \times 10^{6} \mathrm{~m}^{2} \mathrm{~s}^{-1}$ with dashed contours negative and the zero line thickened. Stippling as in Fig. 2.

section using $200 \mathrm{hPa} \chi$ ) was performed. A positive correlation of 0.61 was found among the models (i.e., higher dSST* tends to have less WC weakening). This shows that the rate of SST warming in and around the Maritime Continent (eastern Indian Ocean and western Pacific) is important for modulating the change in WC strength due to climate change (i.e., faster warming may lead to less weakening or in fact strengthening).

\subsection{Response of the Hadley circulation}

In CPLD the annual mean climatology of mass stream function $(\Psi)$ consists of two overturning cells on either side of the equator, with the southern cell being slightly stronger (Fig. 5a). These cells describe the HC: ascent occurs in the equatorial regions, with descent generally occurring in the subtropics. The response in CPLD is largely negative and is centered just north of the equator but encompasses the ascending region of both cells. This implies a weakening of the ascending branch in the $\mathrm{NH}$ and a strengthening in the SH. This general pattern of $\mathrm{HC}$ strength change is consistent with the expected changes due to future climate change as simulated by the CMIP5 coupled models (e.g., Vallis et al., 2015; Bony et al., 2013; He and Soden, 2015; Vecchi and Soden, 2007; Gastineau et al., 2009). There is also strengthening apparent in the descending branch of the $\mathrm{HC}$ in the $\mathrm{NH}$, but model agreement is low.
The HC response in CPLD displays a distinct seasonal cycle because the appearance of two distinct cells is an artifact of taking the annual mean. In fact, in DJF and JJA there exists one dominant cell straddling the equator, ascending in the summer hemisphere and descending in the winter hemisphere (Fig. 5c, e). Henceforth, we refer to the seasonal cells with respect to the hemisphere containing the descending limb. The weakening of the DJF (i.e., NH) cell is very evident in CPLD, with a tendency for greater weakening in the ascending limb (Fig. 5c). One feature that was not apparent in the annual mean is the increase in cell height, as evidenced by the positive $\Psi$ response around $150 \mathrm{hPa}$. This is associated with a well-documented increase in tropopause height consistent with warming tropical SSTs, which through moist adiabatic adjustment, leads to a higher tropopause (e.g., Schneider et al., 2010; Santer et al., 2003; He and Soden, 2015). There is a clear poleward shift of the descending branch of the DJF cell in the mid-lower troposphere, which would imply a poleward shift of the midlatitude eddy-driven jet.

The response of the JJA (i.e., SH) cell also shows weakening that is stronger in the ascending than descending region (Fig. 5e). However, in contrast to DJF, the weakening shows little model agreement (indicated by the lack of stippling), and indeed the JJA cell actually strengthens in two-sixths of models (Fig. 6). This increased uncertainty in the response of the southern $\mathrm{HC}$ has been documented for future climate change (He and Soden, 2015; Ma and Xie, 2012; Vecchi and 


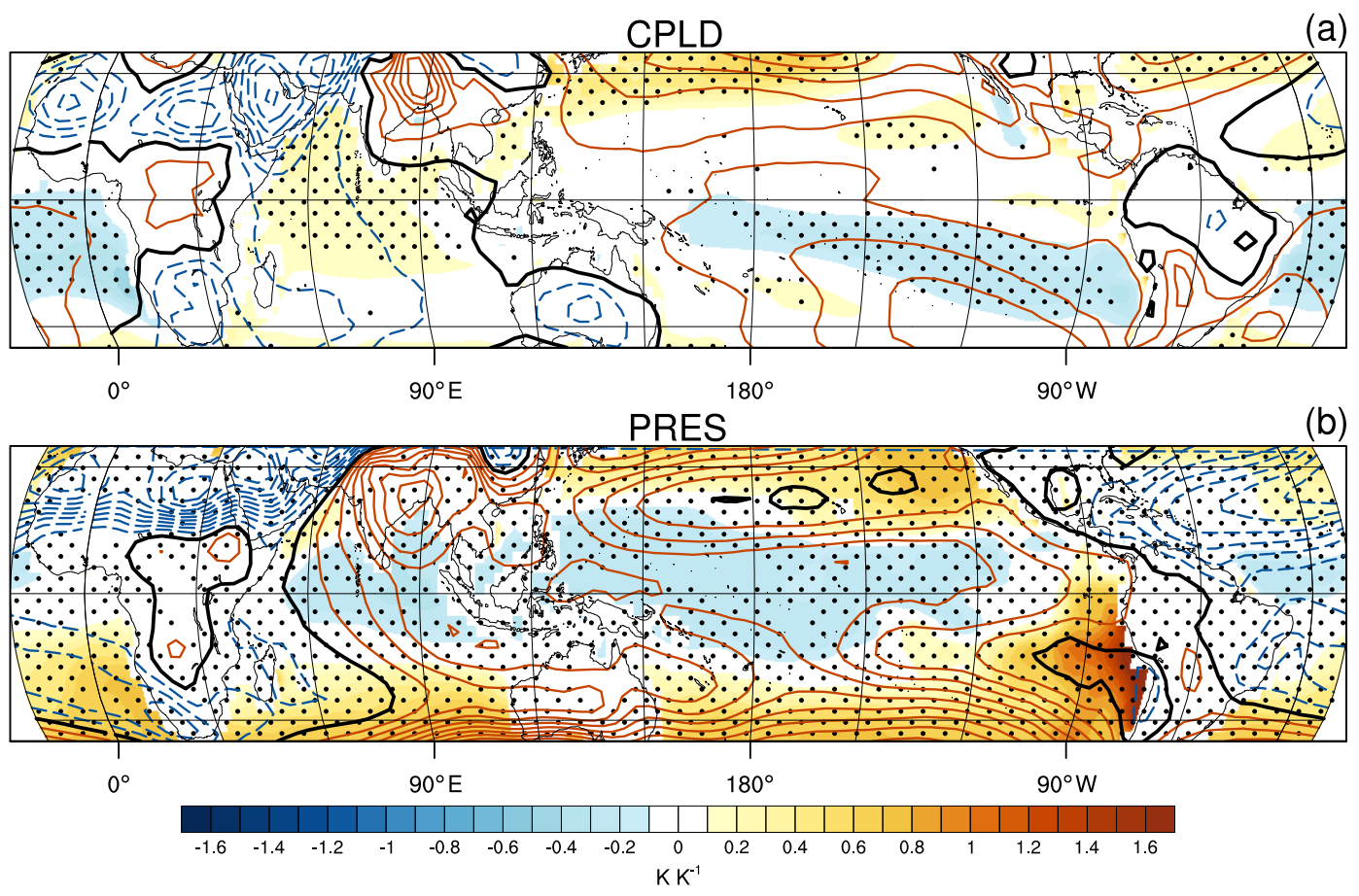

Figure 4. As Fig. 1, except showing the dSST* response (shading) and SLP response (contours, interval $0.2 \mathrm{hPa} \mathrm{K}^{-1}$ with blue as negative, red as positive, and black denoting the zero line). Stippling as in Fig. 2.

Soden, 2007), but to our knowledge this is the first time a similar result has been shown for the mPWP. The increase in tropopause height is stronger in JJA than DJF, and there is a small - but robust - expansion poleward of the descending branch around $30^{\circ} \mathrm{N}$ that mirrors the result in the $\mathrm{NH}$ for DJF (Fig. 5c, e). Given the apparent non-robustness of the $\mathrm{HC}$ weakening response, the robustness of the poleward shift suggests that the strength change and meridional expansion are controlled by different processes. Interestingly, the spatial pattern of the weakening of the JJA cell, and its nonrobustness, are very similar to the response seen among the CMIP5 models for future climate change (e.g., Seo et al., 2014). This has been linked to the slower rate of tropical warming in the SH compared to the NH (e.g., He and Soden, 2015; Ma and Xie, 2012; Vecchi and Soden, 2007; Kang and Lu, 2012; Seo et al., 2014).

Overall, the response of the annual mean $\mathrm{HC}$ is quite different in PRES than in CPLD. In PRES both cells weaken, with the largest weakening in the ascending branch of the southern cell just south of the equator (Fig. 5b). The weakening of the northern HC occurs in the center of the cell, indicating an overall weakening of cell strength, as opposed to a weakening of the ascending branch in CPLD. The southern $\mathrm{HC}$, however, weakens mainly in the ascending region, which is opposite to the strengthening seen there in CPLD. There is a slight poleward expansion of the descending region of the northern HC in PRES, which is more robust in terms of model agreement than in CPLD.
Similar amounts of $\mathrm{HC}$ weakening are found in DJF and JJA in PRES (Fig. 5d, f). However, there are differences in the response around the edges of the cell in each season. There is strong model agreement that in DJF the ascending portion of the cell moves slightly poleward (Fig. 5d), while in JJA both the ascending and descending portions of the cell expand poleward (Fig. 5f). This robust weakening and expansion of the southern $\mathrm{HC}$ in the ascending region is consistent with an expansion of the tropical wet zones described in Sect. 3.1 (Fig. 2b) and with the single AGCM study of Kamae et al. (2011). While this expansion of the $\mathrm{HC}$ is also somewhat evident in CPLD, it is much weaker and only robust for the northern cell (i.e., DJF) in the lower troposphere. An increase in tropopause height is not evident in any season for PRES, which is likely related to the lack of tropical warming in the imposed SSTs in PRES (Fig. 1b). Although PlioMIP temperature data were not archived from model layers in the mid-upper troposphere, we speculate that the warming in that region in PRES would be substantially weaker than in CPLD because of the reduced latent heating driven by muted tropical surface warming (Seo et al., 2014; Santer et al., 2003).

\subsection{Causes of seasonal asymmetry in $\mathrm{HC}$ change}

Next we attempt to provide an explanation for why the largest non-robustness in the $\mathrm{HC}$ response - and the largest differences between PRES and CPLD - occur in JJA. Merid- 

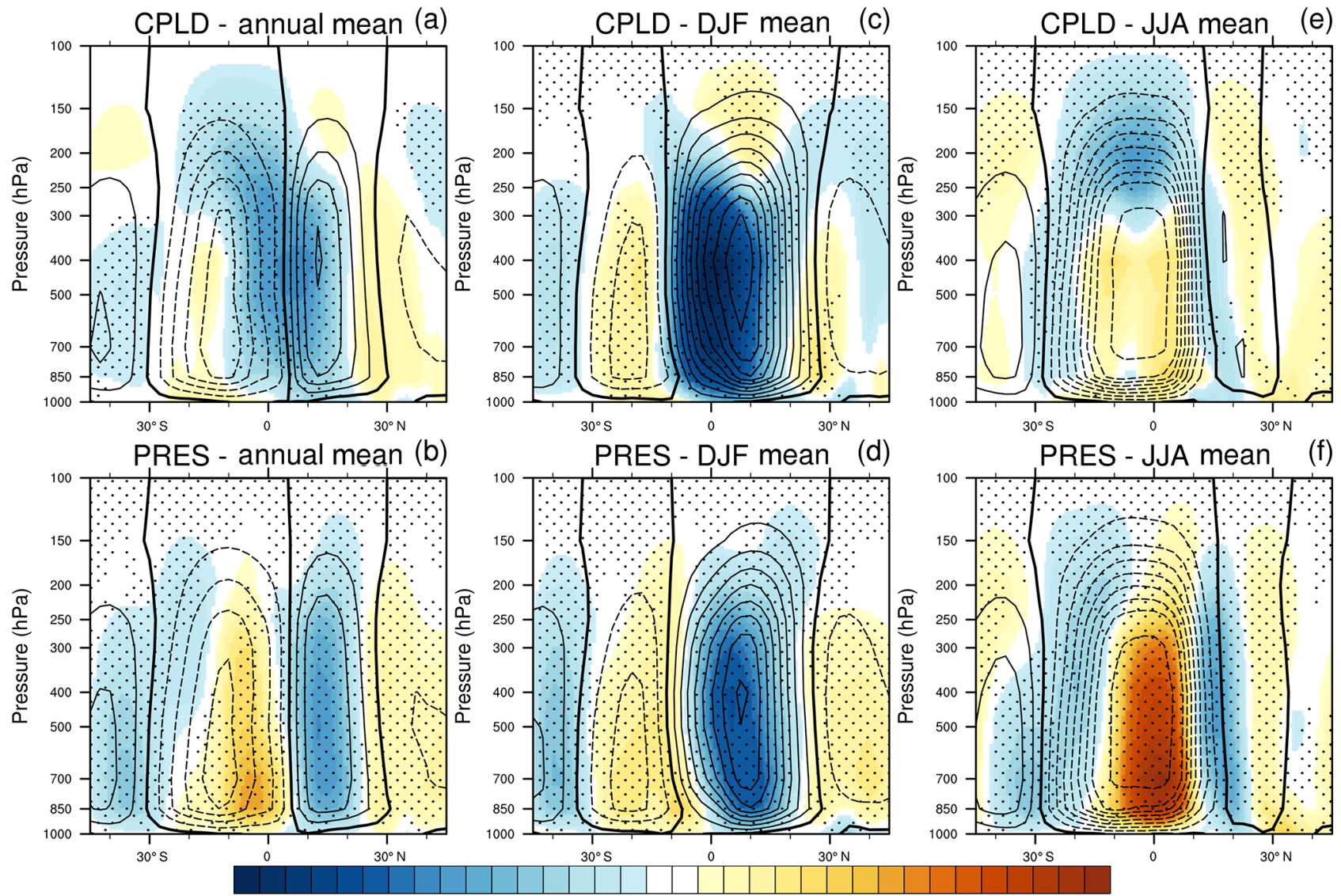

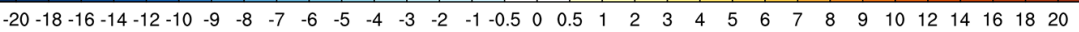

$10^{9} \mathrm{~kg} \mathrm{~s}^{-1} \mathrm{~K}^{-1}$

Figure 5. CPLD (a, c, e) and PRES (b, d, f) meridional mass stream function response (shading) and preindustrial control climatology (contours, interval $2 \times 10^{10} \mathrm{~kg} \mathrm{~s}^{-1}$, with dashed lines as negative and the zero line thickened): (a, b) annual mean, (c, d) DJF mean, (e, f) JJA mean. Stippling as in Fig. 2.

ional gradients in SST and lower-tropospheric temperature between the tropics and subtropics have been shown to affect HC strength in both mPWP and future climates (e.g., Seo et al., 2014; Levine and Schneider, 2010; Williamson et al., 2013; Gastineau et al., 2009; Kamae et al., 2011). We further investigate this mechanism using the quantity dTs, which we define as the change in the meridional surface temperature gradient between the equatorial region $\left(5^{\circ} \mathrm{S}-5^{\circ} \mathrm{N}\right)$ and the northern $\left(15-25^{\circ} \mathrm{N}\right)$ or southern $\left(15-25^{\circ} \mathrm{S}\right)$ subtropics. We compute dTs separately for the two winter hemispheres in each model, then compare the values of dTs with a common measure of $\mathrm{HC}$ strength in each model: the absolute change in the maximum (minimum) value of $\Psi\left(\Delta|\Psi|_{\max }\right)$ for the Northern (Southern) Hemisphere (e.g., Kang et al., 2013).

Figure 6 shows that, to leading order, the seasonal asymmetry in the multi-model mean $\mathrm{HC}$ response in CPLD is explained by differences in dTs. The relatively small change in HC strength during JJA $\left(\Delta|\Psi|_{\max }\right.$ of $-0.01 \times 10^{-11} \mathrm{~kg} \mathrm{~s}^{-1} \mathrm{~K}^{-1}$ in the multi-model mean) is accompanied by a small $\Delta \mathrm{Ts}$ in that season $\left(0.03 \mathrm{~K} \mathrm{~K}^{-1}\right)$, compared to the larger values seen in $\operatorname{DJF}\left(\Delta|\Psi|_{\max }\right.$ of $-0.13 \times 10^{-11} \mathrm{~kg} \mathrm{~s}^{-1} \mathrm{~K}^{-1}, 0.33 \mathrm{~K} \mathrm{~K}^{-1}$ ). In other words, the stronger weakening of the $\mathrm{NH}$ cell than the $\mathrm{SH}$ cell in CPLD could be explained by the subtropics warming faster than the tropics - and the associated weakening of the tropicalsubtropical surface temperature gradient - in DJF, but not in JJA (Fig. 6). This is reminiscent of the result from Seo et al. (2014), who found a significant positive linear relationship between $\Delta|\Psi|_{\max }$ and dTs among a suite of 30 CMIP5 models. However, in our sample of six CPLD models from PlioMIP, we find only a modest relationship $(r=-0.46)$ between dTs and $\Delta|\Psi|_{\max }$, and this only emerges when DJF and JJA data are pooled (not shown). The correlation values for DJF and JJA separately are not significant and show the opposite relationship ( $r=0.39$ and $r=0.14$, respectively).

The reason for the much weaker dTs in the Southern Hemisphere in CPLD is that the southern tropical oceans warm more slowly than the northern tropical oceans (shown in Fig. 4a for the annual mean). This explains the hemispheric asymmetry in dTs, and this pattern is very similar 


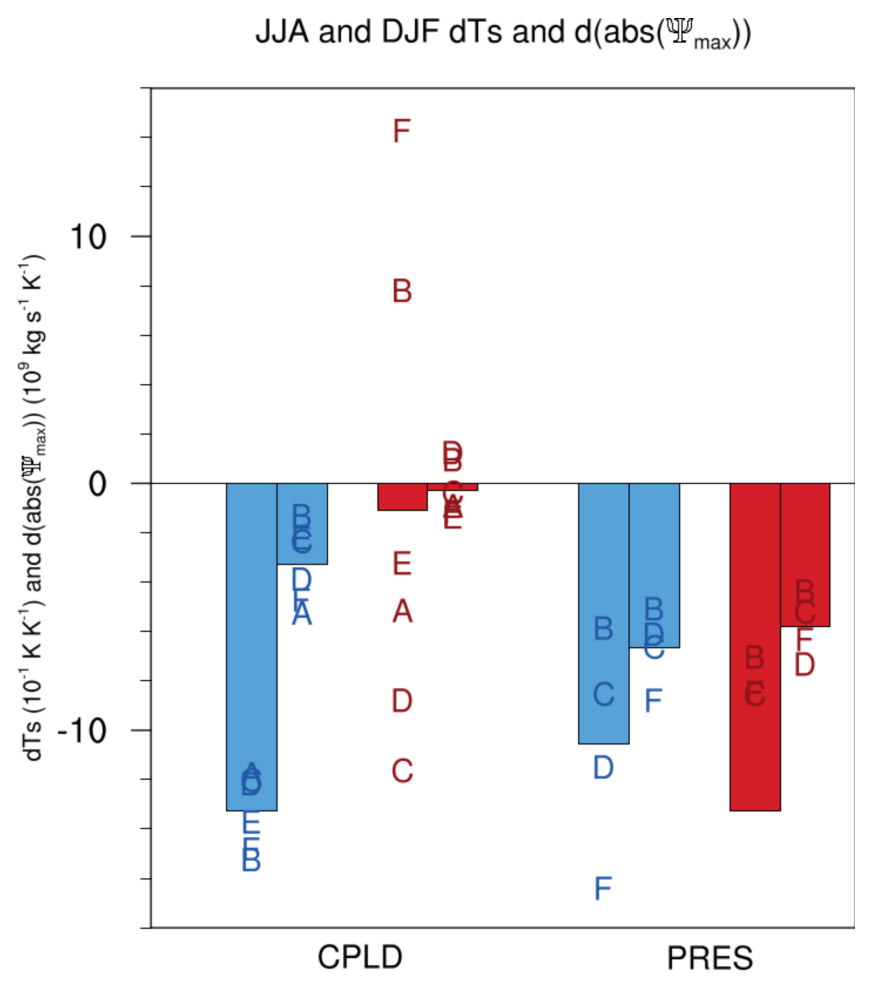

Figure 6. CPLD and PRES multi-model mean DJF (blue) and JJA (red) $\Delta|\Psi|_{\max }$ (left bar of pair) and $\Delta$ Ts (right bar of pair), with individual models indicated by letters (see Table 1 and text for details).

for DJF and JJA (not shown). Therefore, we propose that the seasonal asymmetry in HC response in CPLD is, at least partially, explained by a corresponding asymmetry in the tropical SST warming between the hemispheres. A further demonstration of this idea comes from PRES, where dTs and $\Delta|\Psi|_{\max }$ are very similar in both seasons and hemispheres (Figs. 4b, 6). We note that the hemispheric asymmetry in surface warming found in CPLD, and the associated changes in the $\mathrm{HC}$, are similar to those projected for future climate change from CMIP5 (e.g., He and Soden, 2015).

\section{Discussion and conclusions}

The tropical circulation response in two groups of models in PlioMIP show an overall slowdown of the zonal and meridional components of the tropical overturning circulation. However, we found that there are significant differences in the Walker circulation (WC) and Hadley circulation (HC) response between the two model groups. The ascending branch of the WC weakens, but does so much less in CPLD than in PRES (and less than reported in CMIP5 models by He and Soden, 2015). Across the two experiments we find that the sign and magnitude of the WC response is strongly related to pattern of SST warming, particularly around the Maritime Continent and eastern Indian Ocean. We also find that the change in the winter hemispheric meridional SST gradient between equatorial regions and the subtropics effects the $\mathrm{HC}$ response. We find that the southern subtropics warm more slowly than the northern subtropics in CPLD and there is thus an asymmetry in the $\mathrm{HC}$ response between JJA and DJF.

The dependence of the WC response on the pattern of SST warming is contrary to studies of future climate, where the weakening of the $\mathrm{WC}$ is found to be a robust response to global warming, and is not as strongly related to the spatial pattern of SST warming (e.g., Ma and Xie, 2012). However, there exists a two-way coupling between the WC and SSTs through the Bjerknes feedback (Bjerknes, 1966), making it possible that the models in CPLD exhibit greater Indian Ocean warming precisely because the WC weakens less. In PRES, where SSTs are held fixed, we see a significant weakening of the WC compared to PI, which indicates that the atmospheric changes from global warming weaken the WC. This provides further evidence that the pattern of SST warming in CPLD is working against the overall tendency for WC weakening driven by an increasing atmospheric stability. Only a new set of experiments designed to separate the SST and WC changes, beyond the scope of this study, can fully resolve this problem of cause and effect.

What we have found in PlioMIP for the HC is generally consistent with projections of future climate. Thus, the PlioMIP models indicate that the Pliocene tropical circulation could be similar to near-future (i.e., this century) $\mathrm{HC}$ changes caused by anthropogenic climate change. The HC response of both groups of models is similar to projections of future climate, with CPLD having the most similar response to CMIP5. In fact, the spatial pattern of the CPLD JJA HC response looks incredibly similar to that of the RCP 8.5 CMIP5 response in Fig. 1b in Seo et al. (2014). As we have shown, this similarity is likely explained by the similar meridional asymmetry in tropical SST response in CPLD and CMIP5, with regions in the southern tropical Pacific warming slower than those along and north of the equator. It would seem that the meridional pattern of tropical SST response is a robust response to increased GHGs since it is seen in both the PlioMIP coupled simulations and in CMIP5.

The spatial pattern of tropical circulation response in PlioMIP shows that regions with greater warming of the tropical SSTs tend to see increases in precipitation and upperlevel divergence, i.e., the "warmer-get-wetter" pattern discussed in Ma and Xie (2012). Our results are also in agreement with the single AGCM mid-Pliocene experiments of Kamae et al. (2011) using prescribed SSTs and Sun et al. (2013) using an interactive ocean model, providing support that the details are robust to model configuration. However, it is striking that the pattern of tropical SST warming produced in CPLD is largely inconsistent with the PRISM3 paleoclimate SST reconstructions used as boundary conditions in PRES (Dowsett and Robinson, 2009; Dowsett et al., 2010) (Fig. 1c). We have shown that this has important implications 
for the tropical circulation, and so this requires further urgent investigation if the MPWP is to be considered as a reliable analogue for future climate.

\section{Data availability}

The data archive for PlioMIP phase 1 can be found at https://geology.er.usgs.gov/egpsc/prism/prism_1.23/ prism_pliomip.html (last access: December 2013). The PlioMIP group homepage can be found at http://geology.er.usgs.gov/egpsc/prism/7_pliomip2.html.

Competing interests. The authors declare that they have no conflict of interest.

Acknowledgements. We thank the modeling groups in Table 1 who contributed data to the PlioMIP project. Shawn Corvec and Christopher G. Fletcher acknowledge funding from NSERC Discovery Grant no. 402661.

Edited by: A. Winguth

Reviewed by: two anonymous referees

\section{References}

Bayr, T. and Dommenget, D.: The Tropospheric Land-Sea Warming Contrast as the Driver of Tropical Sea Level Pressure Changes, J. Climate, 26, 1387-1402, doi:10.1175/JCLI-D-11-00731.1, 2012.

Bjerknes, J.: A possible response of the atmospheric Hadley circulation to equatorial anomalies of ocean temperature, Tellus, 18, 820-829, doi:10.1111/j.2153-3490.1966.tb00303.x, 1966.

Bony, S., Bellon, G., Klocke, D., Sherwood, S., Fermepin, S., and Denvil, S.: Robust direct effect of carbon dioxide on tropical circulation and regional precipitation, Nat. Geosci., 6, 447-451, doi:10.1038/ngeo1799, 2013.

Chadwick, R., Boutle, I., and Martin, G.: Spatial Patterns of Precipitation Change in CMIP5: Why the Rich Do Not Get Richer in the Tropics, J. Climate, 26, 3803-3822, doi:10.1175/JCLI-D-1200543.1, 2012.

Dekens, P. S., Ravelo, A. C., and McCarthy, M. D.: Warm upwelling regions in the Pliocene warm period, Paleoceanography, 22, PA3211, doi:10.1029/2006PA001394, 2007.

Dowsett, H. and Poore, R.: Pliocene sea surface temperatures of the north atlantic ocean at 3.0 Ma, Quaternary Sci. Rev., 10, 189204, 1991.

Dowsett, H., Thompson, R., Barron, J., Cronin, T., Fleming, F., Ishman, S., Poore, R., Willard, D., and Holtz, T.: Joint investigations of the Middle Pliocene climate I: PRISM paleoenvironmental reconstructions, Glob. Planet. Change, 9, 169-195, doi:10.1016/0921-8181(94)90015-9, 1994.

Dowsett, H., Barron, J., and Poore, R.: Middle Pliocene sea surface temperatures: a global reconstruction, Mar. Micropaleontol., 27, 13-25, doi:10.1016/0377-8398(95)00050-X, 1996.
Dowsett, H., Robinson, M., Haywood, A., Salzmann, U., Hill, D., Sohl, L., Chandler, M., Williams, M., Foley, K., and Stoll, D.: The PRISM3D paleoenvironmental reconstruction, Stratigraphy, 7, 123-139, 2010.

Dowsett, H. J.: The PRISM palaeoclimate reconstruction and Pliocene sea-surface temperature, in: Deep-time perspectives on climate change: Marrying the signal from computer models and biological proxies, Micropaleontological Society (Special Publication), Geological Society of London, London, UK, 459-480, 2007a.

Dowsett, H. J. and Robinson, M. M.: Mid-Pliocene equatorial Pacific sea surface temperature reconstruction: a multiproxy perspective, Philos. T. R. Soc. A, 367, 109-125, doi:10.1098/rsta.2008.0206, 2009.

Dowsett, H. J., Cronin, T. M., Poore, R. Z., Thompson, R. S., Whatley, R. C., and Wood, A. M.: Micropaleontological Evidence for Increased Meridional Heat Transport in the North Atlantic Ocean During the Pliocene, Science, 258, 1133-1135, doi:10.1126/science.258.5085.1133, 1992.

Gastineau, G., Li, L., and Le Treut, H.: The Hadley and Walker Circulation Changes in Global Warming Conditions Described by Idealized Atmospheric Simulations, J. Climate, 22, 3993-4013, doi:10.1175/2009JCLI2794.1, 2009.

Gill, A. E.: Some simple solutions for heat-induced tropical circulation, Q. J. Roy. Meteor. Soc., 106, 447-462, doi:10.1002/qj.49710644905, 1980.

Haywood, A. M., Dowsett, H. J., Otto-Bliesner, B., Chandler, M. A., Dolan, A. M., Hill, D. J., Lunt, D. J., Robinson, M. M., Rosenbloom, N., Salzmann, U., and Sohl, L. E.: Pliocene Model Intercomparison Project (PlioMIP): experimental design and boundary conditions (Experiment 1), Geosci. Model Dev., 3, 227-242, doi:10.5194/gmd-3-227-2010, 2010.

Haywood, A. M., Dowsett, H. J., Robinson, M. M., Stoll, D. K., Dolan, A. M., Lunt, D. J., Otto-Bliesner, B., and Chandler, M. A.: Pliocene Model Intercomparison Project (PlioMIP): experimental design and boundary conditions (Experiment 2), Geosci. Model Dev., 4, 571-577, doi:10.5194/gmd-4-571-2011, 2011.

Haywood, A. M., Hill, D. J., Dolan, A. M., Otto-Bliesner, B. L., Bragg, F., Chan, W.-L., Chandler, M. A., Contoux, C., Dowsett, H. J., Jost, A., Kamae, Y., Lohmann, G., Lunt, D. J., Abe-Ouchi, A., Pickering, S. J., Ramstein, G., Rosenbloom, N. A., Salzmann, U., Sohl, L., Stepanek, C., Ueda, H., Yan, Q., and Zhang, Z.: Large-scale features of Pliocene climate: results from the Pliocene Model Intercomparison Project, Clim. Past, 9, 191-209, doi:10.5194/cp-9-191-2013, 2013.

He, J. and Soden, B. J.: Anthropogenic Weakening of the Tropical Circulation: The Relative Roles of Direct $\mathrm{CO}_{2}$ Forcing and Sea Surface Temperature Change, J. Climate, 28, 8728-8742, doi:10.1175/JCLI-D-15-0205.1, 2015.

Held, I. M. and Soden, B. J.: Robust Responses of the Hydrological Cycle to Global Warming, J. Climate, 19, 5686-5699, doi:10.1175/JCLI3990.1, 2006.

Hu, Z.-Z., Latif, M., Roeckner, E., and Bengtsson, L.: Intensified Asian Summer Monsoon and its variability in a coupled model forced by increasing greenhouse gas concentrations, Geophys. Res. Lett., 27, 2681-2684, doi:10.1029/2000GL011550, 2000.

Kamae, Y., Ueda, H., and Kitoh, A.: Hadley and Walker Circulations in the Mid-Pliocene Warm Period Simulated by an Atmo- 
spheric General Circulation Model, J. Meteorol. Soc. Jpn., 89, 475-493, doi:10.2151/jmsj.2011-505, 2011.

Kang, S. M. and Lu, J.: Expansion of the Hadley Cell under Global Warming: Winter versus Summer, J. Climate, 25, 8387-8393, doi:10.1175/JCLI-D-12-00323.1, 2012.

Kang, S. M., Deser, C., and Polvani, L. M.: Uncertainty in Climate Change Projections of the Hadley Circulation: The Role of Internal Variability, J. Climate, 26, 7541-7554, doi:10.1175/JCLI-D12-00788.1, 2013.

Kosaka, Y. and Xie, S.-P.: Recent global-warming hiatus tied to equatorial Pacific surface cooling, Nature, 501, 403-407, doi:10.1038/nature12534, 2013.

L'Heureux, M. L., Lee, S., and Lyon, B.: Recent multidecadal strengthening of the Walker circulation across the tropical Pacific, Nature Climate Change, 3, 571-576, doi:10.1038/nclimate1840, 2013.

Laskar, J., Robutel, P., Joutel, F., Gastineau, M., Correia, A. C. M., and Levrard, B.: A long-term numerical solution for the insolation quantities of the Earth, Astron. Astrophys., 428, 261-285, doi:10.1051/0004-6361:20041335, 2004.

Lau, K.-M. and Phillips, T. J.: Coherent Fluctuations of Fxtratropical Geopotential Height and Tropical Convection in Intraseasonal Time Scales, J. Atmos. Sci., 43, 1164-1181, doi:10.1175/1520-0469(1986)043<1164:CFOFGH>2.0.CO;2, 1986.

Levine, X. J. and Schneider, T.: Response of the Hadley Circulation to Climate Change in an Aquaplanet GCM Coupled to a Simple Representation of Ocean Heat Transport, J. Atmos. Sci., 68, 769783, doi:10.1175/2010JAS3553.1, 2010.

Liu, J., Song, M., Hu, Y., and Ren, X.: Changes in the strength and width of the Hadley Circulation since 1871, Clim. Past, 8, 11691175, doi:10.5194/cp-8-1169-2012, 2012.

Lu, J., Vecchi, G. A., and Reichler, T.: Expansion of the Hadley cell under global warming, Geophys. Res. Lett., 34, L06805, doi:10.1029/2006GL028443, 2007.

Ma, J. and Xie, S.-P.: Regional Patterns of Sea Surface Temperature Change: A Source of Uncertainty in Future Projections of Precipitation and Atmospheric Circulation, J. Climate, 26, 2482-2501, doi:10.1175/JCLI-D-12-00283.1, 2012.

Ma, J., Xie, S.-P., and Kosaka, Y.: Mechanisms for Tropical Tropospheric Circulation Change in Response to Global Warming, J. Climate, 25, 2979-2994, doi:10.1175/JCLI-D-11-00048.1, 2011.

McGregor, S., Timmermann, A., Stuecker, M. F., England, M. H., Merrifield, M., Jin, F.-F., and Chikamoto, Y.: Recent Walker circulation strengthening and Pacific cooling amplified by Atlantic warming, Nature Climate Change, 4, 888-892, doi:10.1038/nclimate2330, 2014.

Mitas, C. M. and Clement, A.: Has the Hadley cell been strengthening in recent decades?, Geophys. Res. Lett., 32, L03809, doi:10.1029/2004GL021765, 2005.

Mitas, C. M. and Clement, A.: Recent behavior of the Hadley cell and tropical thermodynamics in climate models and reanalyses, Geophys. Res. Lett., 33, L01810, doi:10.1029/2005GL024406, 2006.

Oort, A. H. and Yienger, J. J.: Observed Interannual Variability in the Hadley Circulation and Its Connection to ENSO, J. Clim., 9, 2751-2767, doi:10.1175/15200442(1996)009<2751:OIVITH>2.0.CO;2, 1996.
Power, S. B. and Kociuba, G.: The impact of global warming on the Southern Oscillation Index, Clim. Dynam., 37, 1745-1754, doi:10.1007/s00382-010-0951-7, 2010.

Raymo, M. E., Grant, B., Horowitz, M., and Rau, G. H.: Mid-Pliocene warmth: stronger greenhouse and stronger conveyor, Mar. Micropaleontol., 27, 313-326, doi:10.1016/03778398(95)00048-8, 1996.

Robinson, M. M., Dowsett, H. J., and Chandler, M. A.: Pliocene Role in Assessing Future Climate Impacts, EOS, 89, 501-502, doi:10.1029/2008EO490001, 2008.

Roundy, P. E., MacRitchie, K., Asuma, J., and Melino, T.: Modulation of the Global Atmospheric Circulation by Combined Activity in the Madden-Julian Oscillation and the El Niño-Southern Oscillation during Boreal Winter, J. Climate, 23, 4045-4059, doi:10.1175/2010JCLI3446.1, 2010.

Salzmann, U., Dolan, A. M., Haywood, A. M., Chan, W.-L., Voss, J., Hill, D. J., Abe-Ouchi, A., Otto-Bliesner, B., Bragg, F. J., Chandler, M. A., Contoux, C., Dowsett, H. J., Jost, A., Kamae, Y., Lohmann, G., Lunt, D. J., Pickering, S. J., Pound, M. J., Ramstein, G., Rosenbloom, N. A., Sohl, L., Stepanek, C., Ueda, H., and Zhang, Z.: Challenges in quantifying Pliocene terrestrial warming revealed by data-model discord, Nature Climate Change, 3, 969-974, doi:10.1038/nclimate2008, 2013.

Santer, B. D., Wehner, M. F., Wigley, T. M. L., Sausen, R., Meehl, G. A., Taylor, K. E., Ammann, C., Arblaster, J., Washington, W. M., Boyle, J. S., and Brüggemann, W.: Contributions of Anthropogenic and Natural Forcing to Recent Tropopause Height Changes, Science, 301, 479-483, doi:10.1126/science.1084123, 2003.

Sasamori, T.: Stability of the Walker Circulation, J. Atmos. Sci., 39, 518-527, doi:10.1175/15200469(1982)039<0518:SOTWC>2.0.CO;2, 1982.

Schneider, T., O'Gorman, P. A., and Levine, X. J.: Water Vapor and the Dynamics of Climate Changes, Rev. Geophys., 48, RG3001, doi:10.1029/2009RG000302, 2010.

Seo, K.-H., Frierson, D. M. W., and Son, J.-H.: A mechanism for future changes in Hadley circulation strength in CMIP5 climate change simulations, Geophys. Res. Lett., 41, GL060868, doi:10.1002/2014GL060868, 2014.

Shin, S.-I. and Sardeshmukh, P. D.: Critical influence of the pattern of Tropical Ocean warming on remote climate trends, Clim. Dynam., 36, 1577-1591, doi:10.1007/s00382-009-0732-3, 2010.

Sohn, B.-J., Lee, S., Chung, E.-S., and Song, H.-J.: The Role of the Dry Static Stability for the Recent Change in the Pacific Walker Circulation, J. Climate, 29, 2765-2779, doi:10.1175/JCLI-D-150374.1, 2016.

Sun, Y., Ramstein, G., Contoux, C., and Zhou, T.: A comparative study of large-scale atmospheric circulation in the context of a future scenario (RCP4.5) and past warmth (mid-Pliocene), Clim. Past, 9, 1613-1627, doi:10.5194/cp-9-1613-2013, 2013.

Taylor, K. E., Stouffer, R. J., and Meehl, G. A.: An Overview of CMIP5 and the Experiment Design, B. Am. Meteorol. Soc., 93, 485-498, doi:10.1175/BAMS-D-11-00094.1, 2011.

Trenberth, K. E., Branstator, G. W., Karoly, D., Kumar, A., Lau, N.C., and Ropelewski, C.: Progress during TOGA in understanding and modeling global teleconnections associated with tropical sea surface temperatures, J. Geophys. Res.-Oceans, 103, 1429114324, doi:10.1029/97JC01444, 1998. 
Vallis, G. K., Zurita-Gotor, P., Cairns, C., and Kidston, J.: Response of the large-scale structure of the atmosphere to global warming, Q. J. Roy. Meteor. Soc., 141, 1479-1501, doi:10.1002/qj.2456, 2015.

Vecchi, G. A. and Soden, B. J.: Global Warming and the Weakening of the Tropical Circulation, J. Climate, 20, 4316-4340, doi:10.1175/JCLI4258.1, 2007.

Vecchi, G. A., Soden, B. J., Wittenberg, A. T., Held, I. M., Leetmaa, A., and Harrison, M. J.: Weakening of tropical Pacific atmospheric circulation due to anthropogenic forcing, Nature, 441, 73-76, doi:10.1038/nature04744, 2006.

Weickmann, K. M., Lussky, G. R., and Kutzbach, J. E.: Intraseasonal (30-60 Day) Fluctuations of Outgoing Longwave Radiation and $250 \mathrm{mb}$ Streamfunction during Northern Winter, Mon. Weather Rev., 113, 941-961, doi:10.1175/15200493(1985)113<0941:IDFOOL>2.0.CO;2, 1985.
Williamson, D. L., Blackburn, M., Nakajima, K., Ohfuchi, W., Takahashi, Y. O., Hayashi, Y.-Y., Nakamura, H., Ishiwatari, M., McGREGOR, J. L., Borth, H., Wirth, V., Frank, H., Bechtold, P., Wedi, N. P., Tomita, H., Satoh, M., Zhao, M., Held, I. M., Suarez, M. J., Lee, M.-I., Watanabe, M., Kimoto, M., Liu, Y., Wang, Z., Molod, A., Rajendran, K., Kitoh, A., and Stratton, R.: The Aqua-Planet Experiment (APE): Response to Changed Meridional SST Profile, J. Meteorol. Soc. Jpn. A, 91, 57-89, doi:10.2151/jmsj.2013-A03, 2013.

Xie, S.-P., Deser, C., Vecchi, G. A., Ma, J., Teng, H., and Wittenberg, A. T.: Global Warming Pattern Formation: Sea Surface Temperature and Rainfall, J. Climate, 23, 966-986, doi:10.1175/2009JCLI3329.1, 2010. 